JDHT Journal of Dental Hygiene and Therapy

Volume 1, Nomor 2 Tahun 2020

ISSN (online) : 2723-1607 DOI: x.xxxxx/jdht.vxix.xx

\title{
PERBANDINGAN PASTA GIGI YANG MENGANDUNG TRICLOSAN DENGAN PASTA GIGI YANG MENGANDUNG BAKING SODA TERHADAP PENURUNAN PLAK
}

\begin{tabular}{|c|c|}
\hline $1 \mathrm{~K}$ & $\begin{array}{l}\text { a Roslinawati }{ }^{1} \text {, Yayah Sopianah }{ }^{2} \text {, M. Fiqih Sabilillah } \\
\text { (watan Gigi Politeknik Kesehatan Kemenkes Tasikmalaya, Indonesia. }\end{array}$ \\
\hline Info Artikel & Abstrak \\
\hline $\begin{array}{l}\text { Genesis Naskah: } \\
\text { Submitted : } 2 \text { September } 2020 \\
\text { Revised }: 10 \text { September } 2020 \\
\text { Accepted :15 September } 2020\end{array}$ & $\begin{array}{l}\text { Pendahuluan: Proporsi menyikat gigi di Indonesia pada tahun } 2018 \text { sebesar } 94,7 \% \text { yaitu } \\
\text { menyikat gigi setiap hari, tetapi hanya } 2,8 \% \text { yang menyikat gigi di waktu yang benar. } \\
\text { Buruknya perilaku dalam menjaga kebersihan gigi dan mulut dapat menyebabkan terbentuknya } \\
\text { plak. Plak adalah suatu lapisan yang merupakan sekumpulan sisa makanan, bakteri, dan } \\
\text { mikroorganisme. Pengendalian plak dapat dilakukan secara mekanis, yaitu menggosok gigi } \\
\text { dengan pasta gigi. Tujuan: Penelitian ini bertujuan untuk mengetahui perbandingan pasta gigi } \\
\text { yang mengandung triclosan dengan pasta gigi yang mengandung baking soda terhadap } \\
\text { penurunan plak. Metode: Penelitian ini menggunakan metode literatur yang bersumber dari } \\
\text { buku, skripsi, dan jurnal. Hasil: Pasta gigi yang mengandung triclosan efektif dapat } \\
\text { menurunkan plak tetapi tidak secara signifikan. Pasta gigi yang mengandung baking soda } \\
\text { efektif dapat menurunkan plak tetapi tidak secara signifikan. Kesimpulan: Pasta gigi yang } \\
\text { mengandung baking soda dapat menurunkan plak lebih besar daripada pasta gigi yang } \\
\text { mengandung triclosan. }\end{array}$ \\
\hline
\end{tabular}

\section{COMPARISON OF TOOTHPASTE CONTAINING TRICLOSAN WITH TOOTHPASTE CONTAINING BAKING SODA TO DECREASE PLAQUE}

\section{Keywords: \\ Plaque, triclosan toothpaste, baking soda toothpaste}

\begin{abstract}
Introduction: The proportion of tooth brushing in Indonesia in 2018 of $94.7 \%$ of tooth brushing every day, but only $2.8 \%$ are brushing the teeth at the right time. Poor behaviour in maintaining dental and oral hygiene can lead to plaque formation. Plaque is a coating that is a collection of leftovers, bacteria, and microorganisms. Plaque control can be done mechanically, namely brushing teeth with toothpaste. Objective: The study aims to determine the comparison of toothpaste containing triclosan with toothpaste containing baking soda to decrease plaque. Method: This study uses literary methods sourced from books, theses, and journals. Result: Toothpaste that contains triclosan can effectively lower the plaque but not significantly. Toothpaste containing baking soda can effectively lower the plaque but not significantly. Conclusion: Toothpaste containing baking soda can lower the plaque larger than the toothpaste containing triclosan.
\end{abstract}

Korespondensi Penulis:

Muhammad Fiqih Sabilillah

Jl. Tamansari No. 210 Gobras Tasikmalaya, Jawa Barat, Indonesia

Email:sabilillah.fiqih@gmail.com

(C) Jurusan Keperawatan Gigi Poltekkes Kemenkes Jakarta I Jl. Wijaya Kusuma No. 47-48 Cilandak Jakarta Selatan, Indonesia email: jdht@poltekkesjakarta1.ac.id 


\section{Pendahuluan}

United Nations Development Programme (UNDP), Indeks Pembangunan Manusia (IPM) mengukur capaian pembangunan manusia berbasis sejumlah komponen dasar kualitas hidup. IPM dibangun melalui pendekatan tiga dimensi dasar, sebagai ukuran kualitas hidup, yaitu umur panjang dan sehat, pengetahuan dan standar hidup layak (Kemenkes R.I, 2017). Menurut Undang-Undang Republik Indonesia Nomor 36 Tahun 2009 kesehatan adalah keadaan sehat, baik secara fisik, mental, spritual maupun sosial yang memungkinkan setiap orang untuk hidup produktif secara sosial dan ekonomis (Sherlyta M., dkk., 2017).

Kesehatan merupakan faktor yang sangat penting dalam kelangsungan hidup manusia, begitu juga dengan kesehatan gigi dan mulut (Sondang \& Harmada., 2008, cit. Puspitasari A., dkk., 2018). Kesehatan gigi dan mulut dapat mempengaruhi kualitas hidup, oleh karena terganggunya fungsi bicara, pengunyahan, dan estetik (Eliza, dkk., 2012, cit. Oroh, dkk., 2015).

Rongga mulut banyak sekali mengandung mikroorganisme. Bahkan, satu mililiter saliva mengandung 200 juta organisme, yang terdiri atas 250 spesies berbeda. Mikroorganisme merupakan mikrobiota normal dalam rongga mulut. Bakteri utama dalam rongga mulut adalah streptococci. Bakteri ini secara konstan berkolonisasi di dalam rongga mulut, terutama di membran mukosa dan gigi (Djamil M.S., 2011).

Riskesdas 2018 mencatat proporsi masalah gigi dan mulut sebesar $57,6 \%$ dan yang mendapatkan pelayanan dari tenaga medis gigi sebesar 10,2\%. Adapun proporsi perilaku menyikat gigi yang baik sebesar $94,7 \%$ yaitu menyikat gigi setiap hari, tetapi hanya 2,8\% yang menyikat gigi di waktu yang benar. Buruknya perilaku dalam menjaga kesehatan gigi dan mulut dapat menyebabkan terbentuknya plak dan meningkatkan perkembangan bakteri di dalam mulut. Sikat gigi rutin dua kali sehari dapat mengurangi pertumbuhan bakteri dan mencegah timbulnya plak (Kemenkes R.I., 2018).

Plak adalah lapisan lunak dan lengket yang melekat pada gigi. Plak terdiri dari protein dan bakteri. 70\% dari bakteri itu berasal dari air liur. Plak terbentuk segera setelah menyikat gigi. Plak mulai mengeras oleh kalsium, fosfor, dan mineral lainnya dan menjadi karang gigi hanya dalam waktu 24 jam setelah pembentukan (Mumpuni dan Pratiwi., 2013).

Penelitian yang dilakukan oleh Bianco, dkk (2009) di Catanzaro, Italia menunjukan bahwa dari 528 subjek yang berumur 11-18 tahun hanya 39\% subjek bebas dari plak gigi, sedangkan sebesar $61 \%$ subyek terdapat plak gigi dengan rata-rata keseluruhan skor plak indeks 0,24 (Shiddiek dan Utami., 2018).

Pengendalian plak dapat dilakukan dengan cara pembersihan plak secara mekanis dan secara kimia dengan bahan anti kuman terutama untuk menekan pertumbuhan bakteri streptococcus mutans. Secara mekanis, menyikat gigi membantu kontrol plak dan merupakan langkah awal untuk mengontrol karies serta penyakit periodontal, baik untuk individu maupun populasi (Inne, dkk., 2013, cit. Oroh, dkk., 2015). Penggunaan pasta gigi pada waktu menyikat gigi merupakan penunjang yang penting (Sukanto., 2012).

Komponen antiplak pada pasta gigi adalah triclosan, papain dan ekstrak sanginaria. Komponen antiplak berfungsi mengurangi pertumbuhan plak. Hal ini dapat berefek terhadap berkurangnya karies dan gingivitis (Pratama, R.N., 2014). Mutmainah (2018), menyebutkan bahwa zat kimia SLS, triclosan dan hidrogen peroksida mempunyai aktifitas antimikroba terhadap $S$. mutans ATCC 25175 dan $C$. albicans ATCC 10231. Zat kimia yang paling aktif terhadap S. mutans ATCC dan C. albicans ATCC 10231 adalah SLS (Sodium Lauril Sulfat).

Komponen pasta gigi lainnya yaitu baking soda (Sodium Bikarbonat) merupakan komponen abrasif pada pasta gigi yang berfungsi menghilangkan plak dan stain gigi (Pratama, R.N., 2014). Randy Nugraha Pratama (2014), menyatakan bahwa efek antibakteri kedua pasta gigi yang mengandung baking soda dan fluor terbukti efektif dalam membunuh bakteri plak, sehingga tidak memiliki perbedaan yang bermakna saat dibandingkan.

Tujuan penelitian untuk: a)mengetahui perbandingan pasta gigi yang mengandung triclosan dengan pasta gigi yang mengandung baking soda terhadap penurunan plak, b)mengetahui efektivitas pasta gigi triclosan terhadap penurunan plak, c)mengetahui efektivitas pasta gigi yang mengandung baking soda terhadap penurunan plak.

\section{Metode}

Metode yang digunakan dalam penelitian ini, yaitu menggunakan metode literatur. Penulisan penelitian ini merupakan hasil telaah dari berbagai teori-teori yang bersumber dari buku-buku dan jurnal yang berhubungan dengan pasta gigi triclosan dan pasta gigi baking soda terhadap penurunan plak. 


\section{Hasil}

Bhopale (2014) melakukan penelitian mengenai pasta gigi yang mengandung triclosan terhadap penurunan plak. Penelitian ini dilakukan selama 3 bulan dengan menggunakan indeks plak Silness dan Loe. Hasil dari penelitian ini menyatakan bahwa tidak ada penurunan plak secara signifikan pada pasta gigi yang mengandung triclosan dengan skor awal pemeriksaan $(1,50 \pm 0,27)$ dengan perbedaan 0,080 , setelah menyikat gigi selama 1 bulan $(1,42 \pm 0,26)$ dengan perbedaan 0,070 , setelah menyikat gigi selama 3 bulan $(1,45 \pm 0,280)$ dengan perbedaan 0,030 .

Aulia Putri Shiddiek, Naning K Utami (2018) melakukan penelitian berjudul "Perbedaan dalam Penggunaan Pasta Gigi yang Mengandung Baking Soda Untuk Menurunkan Skor Plak". Penelitian ini merupakan penelitian analitik dengan jenis penelitian eksperimen semu menggunakan pretest-posttest. Hasil penelitian dari penggunaan pasta gigi yang mengandung baking soda menunjukan kriteria sedang dengan rata-rata plak skor 3,347 menurun menjadi 2,236 dengan tetap dalam kriteria sedang, memiliki selisih nilai 1,089. Kesimpulan penelitian ini menyatakan bahwa penurunan plak tidak terjadi secara signifikan oleh pasta gigi yang mengandung baking soda.

Penelitian yang dilakukan oleh S. Thong, dkk (2015) bertempat di Brunswick USA dengan subyek dalam penelitian ini tidak disebutkan. Penelitian ini membahas mengenai perbandingan pasta gigi yang mengandung triclosan dengan pasta gigi yang mengandung baking soda, diperoleh data penelitian bahwa pasta gigi dengan kandungan 65\% dan 20\% baking soda dapat menghilangkan plak daripada pasta gigi triclosan. Pasta gigi dengan kandungan $65 \%$ baking soda dapat menghilangkan plak secara signifikan daripada pasta gigi dengan kandungan $20 \%$ baking soda.

Penelitian dilakukan selama 4 minggu, subjek melakukan sikat gigi di rumah dengan menggunakan pasta gigi yang mengandung baking soda dan triclosan. Pemeriksaan dilakukan pada awal penelitian dan empat minggu kemudian pada akhir penelitian. Sebelum pemeriksaan, subjek diharapkan untuk menjaga kebersihan mulut selama 24 jam, tidak makan, minum atau merokok pada pagi hari sebelum dilakukan pemeriksaan. Penelitian ini menggunakan pasta gigi dengan tingkat kandungan baking soda yang berbeda, yaitu pasta gigi baking soda dengan kandungan $20 \%$ dan pasta gigi baking soda dengan kandungan $65 \%$. Penilaian plak

(C) Jurusan Keperawatan Gigi Poltekkes Kemenkes Jakarta I Jl. Wijaya Kusuma No. 47-48 Cilandak Jakarta Selatan, Indonesia email: jdht@poltekkesjakarta1.ac.id menggunakan Turesky Modified Quigley-Hein Plaque Index.

Annahita Ghassemi, Linda M. Vorwerk, William J. Hooper (2008) melakukan studi berjudul Enhancement of Plaque Removal Efficacy by Tooth Brushing with Baking Soda Dentifrices: Result of Five Clinical Studies. Data dari lima studi klinis yang berjumlah lebih dari 270 subjek menunjukan bahwa menyikat gigi menggunakan pasta gigi yang mengandung baking soda efektif dalam penurunan plak dengan menunjukan penurunan skor plak yang jauh lebih besar dibandingkan dengan menyikat gigi menggunakan pasta gigi triclosan. Hasil dari lima studi menunjukan untuk perbandingan skor plak menghasilkan bahwa, menyikat gigi dengan pasta gigi yang mengandung 20\% sampai 65\% baking soda dapat menurunkan skor plak lebih besar daripada pasta gigi yang megandung triclosan. Pasta gigi dengan kandungan $20 \%$ baking soda menunjukan penurunan skor plak secara signifikan lebih besar dibandingkan dengan pasta gigi triclosan dengan pengurangan plak $17 \%$ sampai $23 \%$.

Penelitian yang dilakukan oleh Annahita Ghassemi, dkk (2008) bertempat di Fort Wayne USA dengan 207 subjek, 144 subjek wanita dan 63 subyek pria, rentan usia 18 sampai 71 tahun dengan usia rata-rata 39 tahun. Penelitian dengan judul A FourWeek Clinical Study to Evaluate and Compare the Effectiveness of a Baking Soda Dentifrice and an Antimicrobial Dentifrice in Reducing Plaque yang membandingkan efektivitas pasta gigi yang mengandung baking soda dan pasta gigi yang mengandung triclosan dalam mengurangi plak. Penelitian terdiri dari 2 metode yaitu, menyikat gigi tanpa pengawasan yang dilakukan di rumah selama 4 minggu, dan menyikat gigi diawasi di lokasi penelitian selama kunjungan awal dan akhir minggu ke empat. Plak indeks dinilai menggunakan modifikasi Turesky dari Indeks Plakat Quigley-Hein.

Perbandingan skor plak rata-rata setelah dua minggu dan empat minggu menyikat gigi gigi di rumah menunjukan hasil bahwa pasta gigi baking soda dapat menurunkan plak jauh lebih besar daripada pasta gigi triclosan sebesar 1,7 hingga 2,1 kali lipat setelah dua minggu dan 2,0 hingga 2,5 kali lipat setelah empat minggu menyikat gigi.

Hasil perbandingan skor plak rata-rata setelah menyikat gigi tunggal yang diawasi pada kunjungan awal dan kunjungan akhir minggu ke empat. Skor plak sebelum menyikat gigi awal untuk kedua kelompok seimbang, tetapi skor plak sesudah menyikat gigi memiliki perbandingan yang menunjukan bahwa pasta gigi baking soda dapat

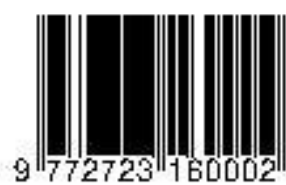


menurunkan skor plak 1,88 kali lipat daripada pasta gigi triclosan yaitu $0,54 \pm 0,26$ untuk pasta gigi baking soda dan $0,28 \pm 0,18$ untuk pasta gigi triclosan. Untuk kunjungan akhir, menyikat gigi menggunakan pasta gigi baking soda menghasilkan perbedaan plak sebelum dan sesudah menyikat gigi secara signifikan lebih besar $0,47 \pm 0,21$ daripada menggunakan pasta gigi triclosan $0,23 \pm 0,15$ dengan 2,08 kali lipat untuk pasta gigi baking soda.

\section{Pembahasan}

Pasta gigi yang mengandung triclosan dan pasta gigi yang mengandung baking soda apabila dibandingkan dengan pasta gigi dengan kandungan lain menunjukan hasil bahwa kedua pasta gigi dapat menurunkan plak tetapi tidak terlihat perbedaan secara bermakna dengan pasta gigi kandungan lain. Triclosan merupakan bahan antibakteri sebagai antiplak, sedangkan baking soda merupakan serbuk putih yang dapat menghambat terjadinya plak.

Triclosan memiliki aktivitas antibakteri berspektrum luas terhadap bakteri dalam plak dan merupakan antibakteri dari golongan fenol yang dapat mengurangi plak, kalkulus, dan mencegah gingivitis (Mutmainah, 2018). Aktivitas mikroba dalam triclosan bekerja dengan cara merusak struktur dan merubah mekanisme pada dinding sel bakteri, selain itu triclosan dapat melisis sel bakteri sehingga sel menjadi mati. Bekerja pada dinding sel dengan mengganggu peningkatan asam amino dan asam nukleat yang dapat berakibat langsung terhadap sintesis RNA dan protein merupakan mekanisme triclosan dalam menghambat pertumbuhan bakteri (Listiyawati, 2006).

Dalam jurnal yang berjudul A Four-Week Clinical Study to Evaluate and Compare the Effectiveness of a Baking Soda Dentifrice and an Antimicrobial Dentifrice in Reducing Plaque oleh Annahita Ghassemi, Linda M. Vorwerk, William J. Hooper (2008) menyebutkan beberapa pertimbangan yang memungkinkan bahwa baking soda dapat mengurangi plak pada saat menyikat gigi, yaitu: pertama, kristal yang terdapat pada baking soda berukuran relatif lebih besar dibandingkan dengan bahan abrasive lain yang bertujuan pada saat menyikat gigi dapat menghilangkan plak dari permukaan gigi. Kedua, ion bikaronat yang terlarut dari baking soda dapat mengikat ion kalsium, sehingga mengurangi ikatan tidak hanya bakteri plak, tetapi juga permukaan gigi yang dimediasi oleh ion kalsium. Ketiga, baking soda dapat mempromosikan aksi deterjen surfaktan dalam pasta gigi karena alkalinitasnya untuk mendukung penetrasi dan

(C) Jurusan Keperawatan Gigi Poltekkes Kemenkes Jakarta I Jl. Wijaya Kusuma No. 47-48 Cilandak Jakarta Selatan, Indonesia email: jdht@poltekkesjakarta1.ac.id gangguan biofilm oral yang lebih baik. Keempat, ion bikarbonat yang terdapat dalam baking soda dapat mengikat ke situs permukaan gigi sehingga memberikan muatan negatif, yang mengakibatkan perpindahan bakteri atau bahan lainnya dalam plak dari permukaan gigi.

\section{Kesimpulan}

Berdasarkan berbagai penelitian dan studi literatur dapat disimpulkan bahwa:

1. Pasta gigi yang mengandung baking soda dapat menurunkan plak secara signifikan daripada pasta gigi yang mengandung triclosan.

2. Pasta gigi yang mengandung triclosan efektif dapat menurunkan plak tetapi tidak secara signifikan.

3. Pasta gigi yang mengandung baking soda efektif dapat menurunkan plak tetapi tidak secara signifikan.

\section{Saran}

1. Bagi Tenaga Kesehatan

Diharapkan tenaga kesehatan dalam menjalankan program pelayanan asuhan kebersihan gigi dan mulut dapat mengkaji lebih banyak sumber dan informasi mengenai penelitian yang berkesinambungan.

2. Bagi Populasi Penelitian

Diharapkan populasi peneliti dapat memperluas wawasan dan ilmu pengetahuan dengan cara mengembangkan kembali, mengkaji lebih banyak sumber dan informasi mengenai penelitian ini agar mendapatkan hasil penelitian yang lebih baik.

3. Bagi Pembaca

Diharapkan pembaca dapat menjadikan pasta gigi yang diteliti sebagai referensi pasta gigi yang berfokus untuk penurunan plak.

\section{Daftar Pustaka}

Bhopale D (2014). Effectiveness of The Chlorhexidine Containing Dentifrice on Reduction of Plaque Gingival Inflammation-A Controlled Clinical Trial. Global Jornal of Medicine and Public Health. Vol. 3. No. 1.

Djamil, M.S. (2011). A-Z Kesehatan Gigi. Solo: PT Tiga Serangkai Pustaka Mandiri.

Ghassemi, A., Linda, M.V., William J.H. (2008). A Four-Week Clinical Study to Evaluate and Compare the Effectiveness of a Baking Soda Dentifrice and an Antimicrobial Dentifrice in Reducing Plaque. The Jornal of Clinical Dentistry. Vol. XIX. No. 4.

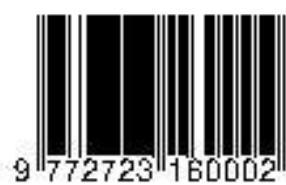


Kementerian Kesehatan Republik Indonesia. (2017). Profil Kesehatan Indonesia Tahun 2016. Jakarta: Kementrian Kesehatan RI, 2017.

Kementerian Kesehatan Republik Indonesia. (2018). Riset Kesehatan Dasar tahun. Badan Penelitian dan Pengembangan, Jakarta

Listiyawati. (2006). Uji Banding Pemakaian Pasta Gigi Yang Mengandung Enzim dan Triclosan Terhadap Pertumbuhan Plak Supragingiva. Naskah Publikasi. Fakultas Kedokteran Gigi Universitas Jember.

Mumpuni, Y., Erlita, P. (2013). 45 Masalah dan Solusi Penyakit Gigi dan Mulut. Yogyakarta: Rapha Publishing.

Mutmainah, S. (2018). Sensitivitas Streptococcus mutans ATCC 25175 dan Candida albicans ATCC 10231 Terhadap Antibakteri Sodium Lauril Sulfat, Hidrogen Peroksida dan Triklosan yang Terkandung dalam Pasta Gigi. Naskah Publikasi. Fakultas Farmasi Universitas Setia Budi Surakarta.

Oroh, E.S., Jimmy, P., Vonny, N.S.W. (2015). Perbandingan Efektivitas Pasta Gigi Herbal Dengan Pasta Gigi Non Herbal Terhadap Penurunan Indeks Plak Gigi. Jurnal e-GIGI $(e G)$. Volume 3 Nomor 2 Juli-Desember 2015.

Pratama, R.N. (2014). Efek Antibakteri Pasta Gigi yang Mengandung Baking Soda dan Pasta Gigi yang Mengandung Fluor Terhadap Pertumbuhan Bakteri Plak. Naskah Publikasi. Bagian Ilmu Kesehatan Gigi Masyarakat Fakultas Kedokteran Gigi Universitas Hasanuddin.
Puspitasari, A., Merlya, B., Abdurrahman, A. (2018). Perbedaan Pasta Gigi Herbal dan Non-Herbal Terhadap Penurunan Plaque Index Score Pada Anak. E-Prodenta Journal of Dentistry. 2(1): 116-123.

Sherlyta, M., Riana, W., Sri, S. (2017). Tingkat kebersihan gigi dan mulut siswa Sekolah Dasar Negeri di desa tertinggal Kabupaten Bandung. J Ked Gi Unpad. 29(1):69-76.

Shiddiek, A.P., Naning, K.U. (2018). Perbedaan dalam Penggunaan Pasta Gigi yang Mengandung Xylitol dan Baking Soda Untuk Menurunkan Skor Plak Pada Siswa SMPN 6 Banjarbaru. Jurnal Kesehatan Gigi. Vol. 05. No. 2, hlm. 47-51.

Sukanto. (2012). Metode Pemilihan Pasta Gigi Yang Tepat Untuk Anak Usia Dini. IDJ. Vol. 1 No. 2, hlm. 28.

Thong, S., dkk. (2011). Enhancement of Plaque Removal by Baking Soda Toothpaste from Less Accessible Areas in the Dentition. The Journal of Clinical Dentistry. Vol. XXII. No. 5, hlm. 171-178. 